\title{
Proximate Levels of Bone Bluefin Tuna Fish As Gelatinization By Product
}

\author{
Suci Istiqlaal \\ (Research and Development of East Nusa Tenggara Province)
}

\begin{abstract}
This purpose of this study was to determine a proximate level of bluefin tuna fish bone as gelatin processing byproduct has been done by the Research and Development of East Nusa Tenggara province. The solvent used is 3\% palm acid, 3\% hydrochloric acid and compared with the control. The data were processed using variance analysis (ANOVA), if there are differences among the treatments then continued with Duncan test using software SPSS.22. The results indicated that proximate level of residual bones affected by gelatin processing. The proximate levels include the levels of protein, fat, water, ash and carbohydrates respectively in TO is as follows 9.65\%, 28.88\%, 5.82\%, 54.79\% and 0.853\%. In TA was $10.23 \%, 27.24 \%, 8.67 \%, 53.53 \%$ and $0.32 \%$, while the fresh tuna fish bones contain protein content of $9.45 \%, 26.57 \%$ fat content, moisture content 8 , 80\%, 55.14\% ash content and carbohydrate content of 0.037\%. Residual bones of gelatin processing are rich with ash content, so be potentially be processed into the bone meal as a source of minerals.
\end{abstract}

Keywords: Proximate level, Residual tuna fish bone of gelatin processing.

\section{Introduction}

Tuna is a large pelagic fish are found in all waters, including waters of East Nusa Tenggara province. Tuna fishing region the majority are in the Pacific Ocean and the Indian Ocean. Particularly in Indonesia, tuna fish habitat was encountered on the southern side of the island of Java, combed to the eastern part of Indonesia. For example, bluefin tuna species were encountered up to the waters of East Nusa Tenggara (NTT). These fish are generally used for the production of canning and freezing, either whole or in the form of frozen loin. Products frozen tuna mostly only use the meat, while the remnants of other uses such as heads, fins, and bones have not been used optimally, so the potential to contaminate the environment for fishery products are perishable products and foul (perishable) (Riry et al., 2013).

In response to the Agency for Research and Development (BPPD) NTT province has been doing research in the fiscal year 2016 about waste treatment tuna fish bones into gelatin using shredded material (hydrolysis) organic. Based on these results, in addition to producing gelatin as the main products, by-products obtained potential for processing into products economical, among other fish bone oil, solvent and remaining shredded tuna fish bones. Notwithstanding the provisions CCRF (Code of Conduct for Responsible Fisheries), the business processing of fishery products must be made more optimal and environmentally friendly (Agustini et al., 2011).

Research conducted by Kantun et al. (2015) demonstrated that chemically tuna loin potentially solid waste is processed into food diversification. According Trilaksani et al. (2006) Bone Fish is one form of waste from the fish-processing industry which contain calcium most among the body parts of fish, because the main element of fish bones are calcium, phosphorus, and carbonate, so that the bones of tuna remainder of the processing of gelatin, still has the potential to be utilized as other products as a source of calcium. In food in general levels of phosphorus (P) never deficiency, but rather levels of calcium $(\mathrm{Ca})$ is often deficient.

Utilization of calcium powder can be applied to the various types of food and non-food products. Considering fish and other animal food is one determinant of the balance of nutrients to form a pattern of ideal consumption, as measured by a score of Dietary Pattern Hope (PPH) (Baliwati and Iqbar, 2014), so before it is processed into other products, basic knowledge should be known is the chemical content in the form of proximate levels. Various ways postharvest processing is done to produce a processed product diversification and to improve the nutritional (Haryati et al., 2006; Desniar et al., 2009).

Been many studies of bone proximate content of fresh tuna and other fish, as has been done by Bykov (1983) tuna fish bones contain water 56.4\%, $11.4 \%$ ash, $17.5 \%$ protein and $12.5 \%$ fat, Nurilmala et al. (2006) explains that the water content of tuna fish bones for $12.57 \%$, ash content of $52.36 \%, 26.02 \%$ protein content and fat content of $8.01 \%$. Fishbone used as a source of calcium in processed products (Kusumaningrum and Asikin, 2016). However, information about the content of the bone proximate the tuna as the rest of the manufacture of gelatin is not known, but according to Purwaningsih et al., 2014; Jacoeb et al, 2015 Chemical composition of fish affected by the manufacturing process, so the researchers felt the need to do research with the aim to determine the chemical content in the form of bone proximate levels of bluefin tuna rest of the manufacture of gelatin. 
Materials and Tools

\section{Materials And Methods}

The materials used are the bones of tuna which is the remainder of the fillet processing by private companies in the district of Kota Kupang Alak. The tools used in this study are digital scales, bottle size 5-liter jerry cans, glass funnel, filter cloth, glass jars, hot plate, glass Bekker size of $1000 \mathrm{ml}, 1000 \mathrm{ml}$ Erlenmeyer size, funnel, evaporation tools, non-stick pan.

\section{Research Methods}

Manufacture of gelatin includes three stages, namely raw material preparation, soaking and stage of the crop using the procedure Istiqlaal and Darmakusuma (not publication). The marinade solution used was 3\% hydrochloric acid (inorganic) and ejection acid 3\% (organic).

\section{Analysis Procedures}

The research design uses a completely randomized design (CRD) of the factors that consisted of three treatments, bone leftover marinade using $\mathrm{HCl}$ (TA), Acid Lontar (TO) and fish bones untreated (TS), each treatment was repeated 3 (three times. Tuna fish bone proximate analysis using AOAC method (2005) to determine levels of protein, fat, water, ash, and carbohydrate. The data obtained were processed using analysis of variance (ANOVA), and if the results show no significant difference, then continued with Duncan test. The data were processed using SPSS.22 application.

\section{Results And Discussion}

\section{Protein levels}

Based on the analysis, there were significant differences in protein content between treatments. Although a solution of hydrochloric acid is a strong acid with the ability to hydrolyze collagen into gelatin, but it turns out the TA protein content higher than TS and TO.

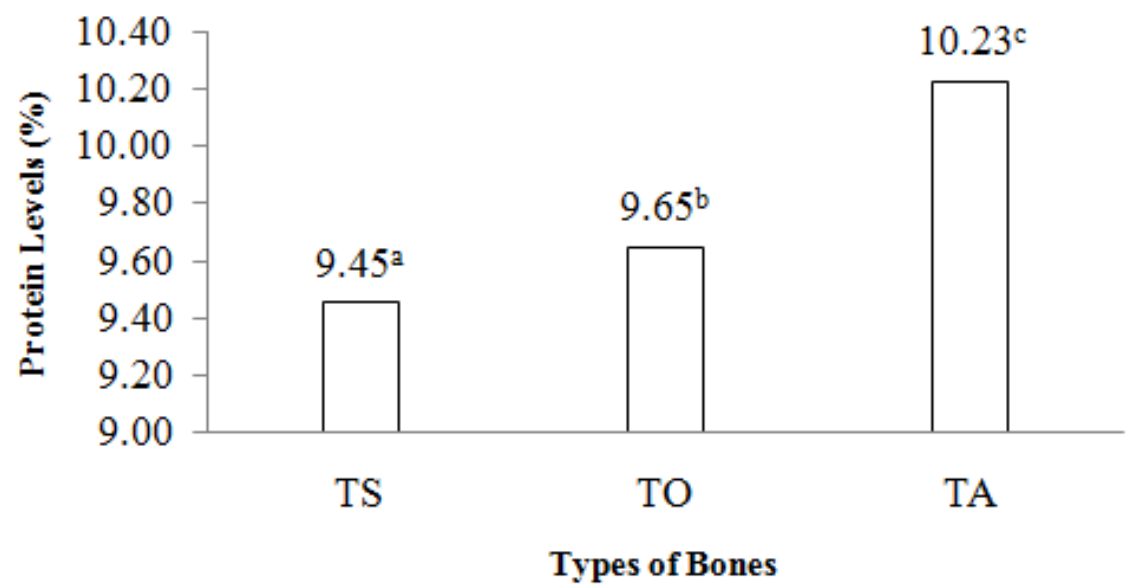

Figure 1. Average value of tuna fish bone protein levels

Based on dry weight, gelatin consists of $98-99 \%$ protein (Keenan in Rush, 2004). Wiratmaja (2006) gained the largest chemical levels in the gelatin from the bones of tuna is a protein of $91.01 \%$. The protein content is closely related to the percentage of other chemical levels, meaning that any changes in the levels of misspent only then will affect the value of the percentage in other chemical levels. Their non-component proteins such as fats and minerals will reduce the percentage of protein content. There is an inverse relationship between protein and water content, the higher the protein content of the lower water content (Buckle et al, 1987). This is according to the results of research Nurjanah et al. (2005) in which the protein levels in the blood clam meat increased from 19:48\% to $76.00 \%$. Increased levels of this protein caused by the decrease of water content in the sample observations from $74.37 \%$ to $0 \%$. from wet to dry conditions.

The protein content in this study both treatment TS, TO and TA is lower than the levels of protein in the meat fresh tuna 23.2\% Wahyu (2011), Wellyana et al. (2013) gained 20.64\%, Nurilmala et al. (2006) gained $26.02 \%$ in the bones of tuna, Kantun et al. (2015) obtain the protein content of the solid waste tuna ranged from 14.32 to $16.41 \%$. In addition to processing, there are other factors which affect protein content as described by Kantun et al (2015) found a high protein content due to dietary factors, the seasons and the movement of fish, whereas low levels of the protein are affected by the environment, temperature, and age of the fish. 


\section{Fat level}

The main nutrient-rich fish protein, mineral, and fat as well as the largest producer of omega-3 fatty acids are beneficial for health (Soccol and Oetterer, 2003). Based on the test results, treatment processes significantly affect bone fat content tuna. Tuna fish bone gelatin processing residual organic (TO) has the highest level of $28.88 \%$, followed by TA amounting to $27.24 \%$ and $26.57 \%$ TS (Figure 2).

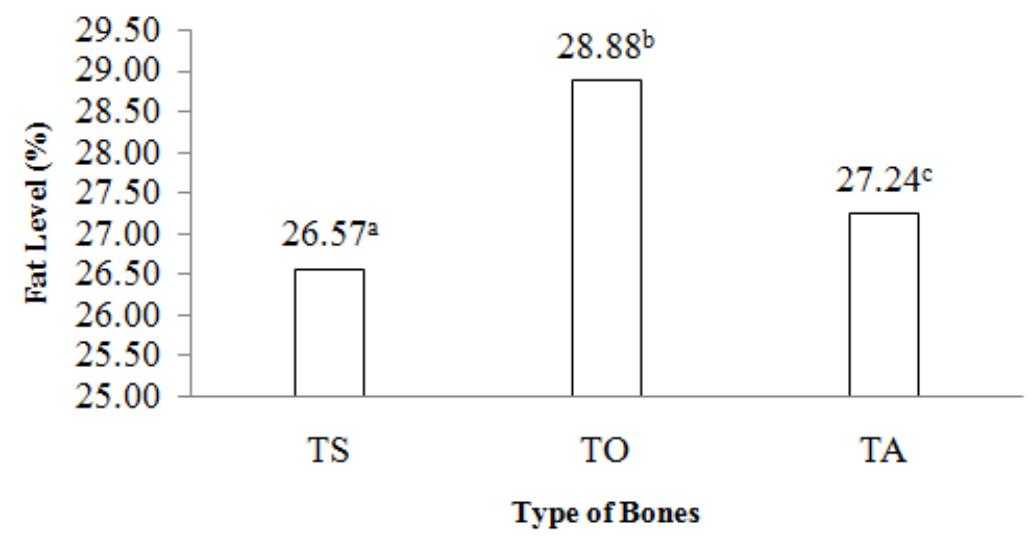

Figure 2. Average value of tuna fish bone fat content

Although the two types of bone that are TO and TA have gone through the process of heating the raw material preparation stage, but has a different final fat content. This difference is caused by the influence of the type of acid used in gelatin hydrolysis stage in which the inorganic acid (hydrochloric acid) was able to reduce the fat content more than organic acids (palm acid) in fish bones. Soaking bone in acid hydrolysis of fat causes that produce fatty acids and glycerol. In fish suffering from boiling will occur hydrolysis of collagen and coagulation proteins, albumin and globulin will undergo denaturation. As a result of coagulation proteins and cell disassembly during boiling, the meat will release the fat and water, nitrogen substance, as well as salts and water-soluble vitamins (Zaitzev et al. 1969).

In addition to influence the final level, the type of acid solution also affect the physical condition of the resulting fat. In the ejection acid solutions, fat produced is still in good condition is characterized by a bright yellow color and the shape of the oil at room temperature, as well as when stored in the refrigerator. This indicates the content of EPA and DHA in the oil tuna fish bones. But not so with the fat produced from the hydrolysis using hydrochloric acid (inorganic). Fat produced is not a liquid (oil) but in a damaged condition. According to Ishihara and Saito (1996), marine fish such as tuna are rich in omega 3 types of DHA, and its existence is contained in the entire body of the fish (meat, skin, viscera and bones).

The fat content obtained in this study is higher compared with other research. Kantun et al. (2015) gained fat content ranging between $1,56-1,66 \%$, the low-fat content is influenced by the proportion of high moisture content is 78.34 to $78.78 \%$. Wellyana et al. (2013) gained $1.6 \%$ and the fat content Nurilmala et al. (2006) gained $8.01 \%$ on the bones of tuna. Fish categorized high fat if the fat content is more than $4 \%$, while the opposite is considered a low-fat fish if the fat content is less than 4\% (Hadiwiyoto, 1993).

\section{Water Level}

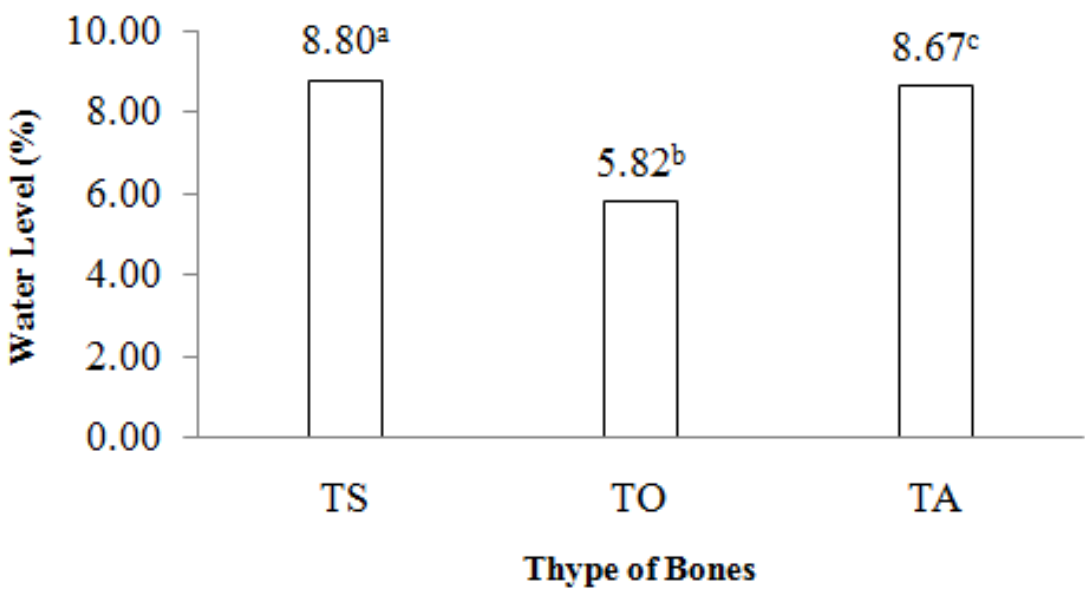

Figure 3. The value of the average moisture content of tuna fish bones 
The results of the analysis of the water content of tuna fish bones from three treatments showed no significant difference $(\mathrm{P}<0.05)$. The water content of the fish bones ranged between $5.82-8.80 \%$. The highest levels found in TA treatment, followed by TS and then TO. Low levels of water in the treatment of TO and TA due to the immersion process using acids, which add acid to accelerate the evaporation of water in the bone when dried so that the water content is reduced. A similar sentiment was expressed by Ahza and Slamet (1997) that the bones in an acid marinade over 4 hours, making the more rapid evaporation due to evaporation of orange juice is more optimal, so that the water content decreases.

When compared to other studies, the water content obtained lower. In the solid waste tuna water content ranged between 78.30-78.81\% (Kantun et al, 2015), Wahyu (2011) obtain a water content of yellowfin tuna in the flesh in a fresh state by $74.0 \%$ and $56.43 \%$ Wellyana et al. (2013), and $12: 57 \%$ on the bone (Nurilmala et al. 2006). Other studies fish get water content ranged 65,88- 68,6- 78.62\% and $77.10 \%$ (Mazumder et al., 2008; Aberoumad and Pourshafi, 2010).

\section{Ash Level}

According to Kadam and Prabhasankar (2010), fishbone is a source of calcium because it consists of a compound of calcium and phosphorus balance. In addition to calcium, the primary mineral found in many fish is $\mathrm{Fe}$, and $\mathrm{Zn} \mathrm{Cu}$ (Le et al., 2009). Minerals play an important role in the functioning of hormones, enzymes and enzyme activity (Kirkpatrick and Coffin, 1974; Khan et al., 1987).

The analysis showed the highest ash content contained in TS treatment amounted to $55.14 \%$, followed by TO amounted to $54.79 \%$ and then amounted to $53.53 \%$ TA. The largest component is contained in bones is calcium. Calcium is present in various forms such as calcium phosphate, calcium citrate, and calcium acetate. Compared to other body parts, bone contains a higher ash content. Tuna fish liver contains $1.3 \%$, fresh meat 1.01\%, 5.58\% solid waste (Kantun et al., 2015; Lopez and Nova, 2013; Wellyana et al., 2013). Meanwhile, according to its kind, the highest ash level contained in the type of $1.77 \%$ bigeye tuna, yellowfin tuna and skipjack tuna 1.54\% 1.43\% (Mahaliyana et al., 2015 and Peng et al., 2013). Her high ash content in the treatment of TS suspected to be caused by the lack of effect of soaking treatment by hydrolysis solution. With the process of hydrolysis, a mineral found in bone come out and deposited on the immersion solution, this causes levels to drop ash on TO and TA. Inorganic acid has the ability to hydrolyze stronger than organic, as seen by the appearance of the rest of the bone where the rest of the immersion soaking lime inorganic issued more than the organic (Figure 4).
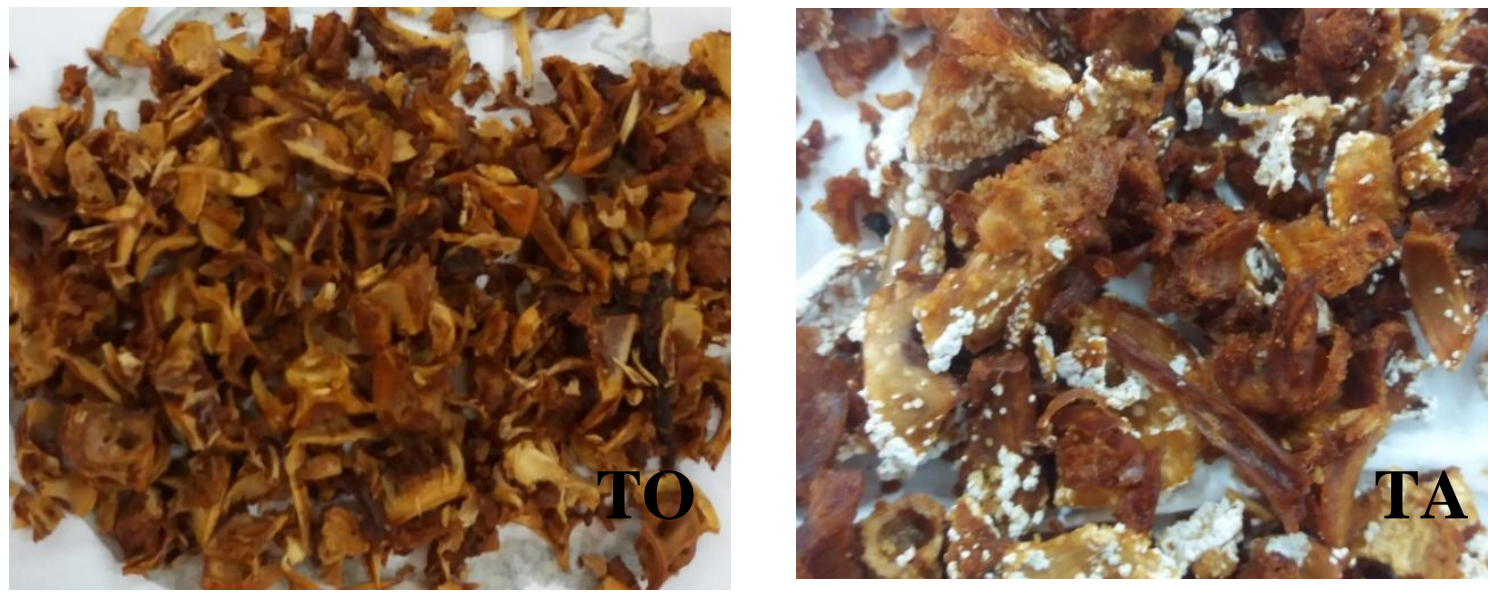

Figure 4. The appearance is soaking residual bone organic acids and inorganic acids

\section{Carbohydrate Level}

Carbohydrates are the main source of calories and when compared with the proteins and fats, carbohydrates are a source of cheap calories (Hadiwiyoto, 1993). Carbohydrate levels in this study ranged between $0.037 \%-0.853 \%$, with the highest levels found in the treatment of TO and the lowest in the treatment of TS.

TO treatment using acid solution ejection and based on test results in previous studies of glucose in a concentration of 7.5 to $20.0 \%$. During the process of hydrolysis, acid solution ejection diffused on the entire surface of the bone tissue and did not rule out when the extraction process is no simple sugars left and attaches to the rest of the organic bone gelatine manufacturing process, so that the levels of carbohydrates TO is higher than the TA and TS. Nonetheless, the carbohydrate content in tuna fish bone is relatively lower compared to other body parts. Kantun et al (2015) obtained carbohydrate content in solid waste amounting to 1.29 to $1.34 \%$ tuna, fresh tuna meat by $1.00 \%$ (Wahyuni, 2011). But higher than the hearts of tuna, which amounted to $0.1 \%$ (Lubis and Nova, 2013). 


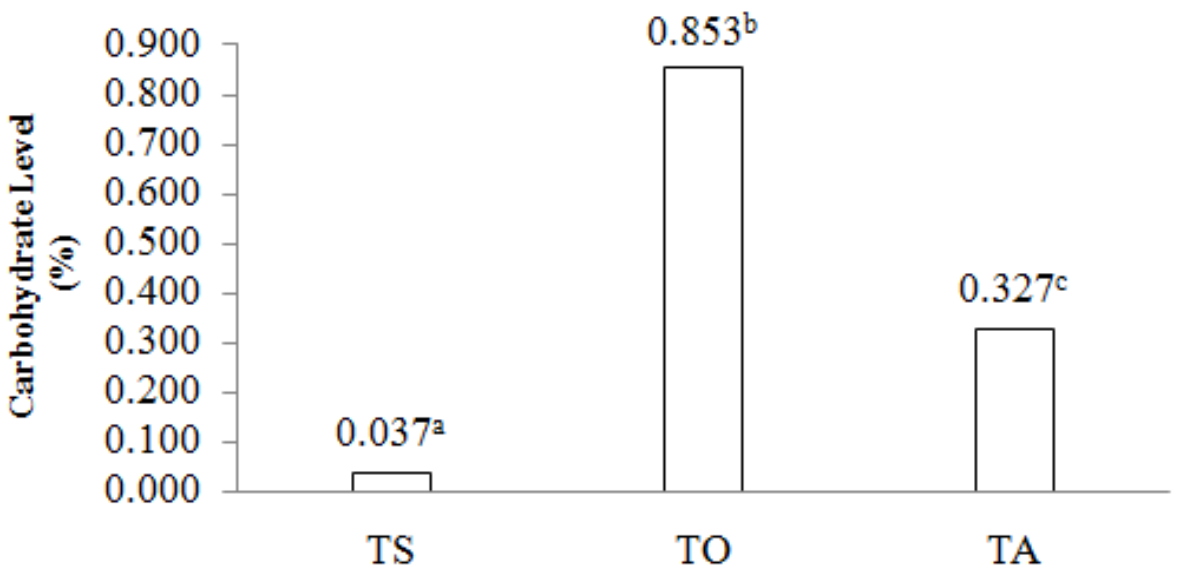

Types of Bones

Figure 5. Average value of tuna fish bones carbohydrate levels

\section{Conclusion}

The results showed that there are significant processing of organic and inorganic gelatin to bone proximate levels of production scrap. The proximate levels include the levels of protein, fat, water, ash and carbohydrates respectively at TO was $9.65 \%, 28.88 \%, 5.82 \%, 54.79 \%$ and $0.853 \%$. In FY was $10.23 \%, 27.24 \%$, $8.67 \%, 53.53 \%$ and $0.32 \%$, while the fresh tuna fish bones protein levels of $9.45 \%, 26.57 \%$ fat content, moisture content $8,80 \%, 55.14 \%$ ash content and carbohydrate levels of $0.037 \%$. Most of the rest of the manufacture of gelatin-containing bone ash content is high, so they could potentially be processed into a bone meal as a source of minerals.

\section{References}

[1]. Aberoumad A dan Pourshafi K. 2010. Chemical and Proximate Composition Properties of Different Fish Species Obtained from Iran. World Journal of Fish and Marine Sciences 2(3), 237-239.

[2]. [AOAC] Association of Official Analytical Chemist. 2005. Official Method of Analysis of The Association of Official Analytical of Chemist. Arlington: The Association of Official Analytical Chemist. Inc.

[3]. Agustini TW, Fahmi AS, Widowati I, Sarwono A. 2011. Scallop Shells Shells Waste Utilization (Amusium Pleuronectes) In Making Cookies Rich in Calcium. The Journal of Fishery Products Processing Indonesia 14(1): 8-13.

[4]. Baliwati YF dan Iqbar MS. 2014. Analysis of Independence Fish And Food Animal 26 District/Municipality in West Java in 2012. The Journal of Fishery Products Processing Indonesia 17 (3) : 186- 196.

[5]. Buckle KA, Edward RA, Fllet GH, Wootton N. 1987. Food Science. The second edition. Translators: Purnomo H, adiono. Food Science. Jakarta: Universitas Indonesia.

[6]. Bykov V P. 1983. Marine Fishes Chemical Composition and Processing Properties. American Publishing Co.PVt. Ltd, New Delhi.

[7]. Desniar, Poernomo D, Wijatur W. 2009. Effect of Salt concentration on Bicycles Mackerel (Rastrelliger sp.) with Spontaneous Fermentation. Journal of Fishery Products Processing Indonesia 12(1): 73-87.

[8]. Hadiwiyoto S. 1993. Fishery Products Processing Technology. Jilid I. Yogyakarta: Liberty.

[9]. Haryati SL, Sya'rani, Agustini TW. 2006. Study Flour Substitution Mackerel, Rebon, Crabs in Various Voncentrations on the Quality of Physicochemical and Organoleptic Instant Noodles. Sea Sand of Journal 392(1): 37-51

[10]. Ishihara K dan Saito H. 1996. The Docosahexaenoic Acid Content of the Lipid of Juvenile Bluefin Tuna Thunnus thynnus Caught in the Sea off Japanese Coast. Fisheries Science 62(5): 840-841.

[11]. Jacoeb AM, Suptijah P, Kristantina WA. 2015. The Composition of Fatty Acids, Cholesterol, and Network Description Fresh Red Snapper Fillet Dan Fried. Journal of Fishery Products Processing Indonesia 18 (1):98-107.

[12]. Kantun F, Malik AA, Harianti. 2015. Solid Waste Feasibility Loin Yellowfin Tuna (Thunnus Albacores) For Raw Materials Diversified Products. Journal of Fishery Products Processing Indonesia 18(3):303-314.

[13]. Khan AH, Ali M, Biaswas SK dan Hadi DA. 1987. Trace elements in marine fish from the Bay of Bengal. The Science of the Total Environment 61:121-130.

[14]. Kirkpatrick DC dan Coffin DE. 1974. The trace metal content of representative Canadian diets in 1970 and 1971.Canadian Institute of Food Science and Technology Journal, 7:56-58

[15]. Kusumaningrum I dan Asikin AN. 2016. Calcium fortification Characteristics Of Fish Crackers Fish Bone Belida. Journal of Fishery Products Processing Indonesia 19(3): 233-240.

[16]. Le, QD, Shirai K, Nguyen DC, Miyazaki N dan Arai T. 2009. Heavy Metals in a Tropical Eel Anguilla Marmorata from the Central Part of Vietnam. Water, Air, and Soil Pollution, 204:69- 78.

[17]. Lubis M R dan Nova M. 2013. Leaching of Oil Tuna fish Liver by Using Solvent of Methyl- Ethyl Ketone. Journal of Chemical and Environmental Engineering 9(4):188-196.

[18]. Mahaliyana AS, Jinadasa BKKK, Liyanage NPP, Jayasinghe GDTM dan Jayamanne SC. 2015. Nutritional Composition of Skipjack Tuna (Katsuwonus pelanis) Caught from the Oceanic Waters around Sri Lankae. American Journal of Food and Nutrition 3(4): 106-111.

[19]. Mazumder MSA, Rahman MM, Ahmed, ATA, Begum M dan Hossain MA. 2008. Proximate Composition of Some Small Indigenous Fish Species (SIS) in Bangladesh". International Journal of Sustainable Crop Production, 3(4):18 -23. 
[20]. Nurilmala MM, Wahyuni dan Wiratmaja H, 2006. Repair Bone Waste Added Value Tuna (Thunnus sp.) Into Gelatin as Well as Physical-Chemical Analysis. Bulletin of Fishery Product Technology 9 (2):22-31.

[21]. Nurjanah, Zulhamsyah dan Kustiyariyah. 2005. Mineral content of Proximate Shells And Blood (Anadara granosa) Taken From Boalemo District, Gorontalo. Bulletin of Fishery Product Technology 8(2):15- 24.

[22]. Peng S, Chen C, Shi Z dan Wang L. 2013. Amino Acid and Fatty Acid Composition of the Muscle Tissue of Yellowfin Tuna (Thunnus albacares) and Bigeye Tuna (Thunnus obesus)". Nature, 1(4): 42- 45.

[23]. Purwaningsih S, Salamah E, Dewantoro R. 2014. Chemical Composition And Fatty Fish Glodok Due to High-Temperature Processing. Journal of Fishery Products Processing Indonesia 17(2): 165-174.

[24]. Riry J, Vita N L, Elizabeth J T, Risyart A F. 2013. The Organoleptic of Fortified Enbal (Local Food of Kei Islands) Based on The Consumers Acceptance. Journal of Fishery Products Processing Indonesia 16 (3): 259-267.

[25]. Rusli A. 2004. Study the Extraction Process of the Skin Gelatin Fresh Catfish. [Thesis]. Bogor: The Graduate School. Bogor Agricultural Institute.

[26]. Soccol M C H dan Oetterer M. 2003. Seafood and Functional Foods. Brazilian Archives of Biology and Technology. An International Journal 46: 443-454.

[27]. Trilaksani W, Salamah E, Nabil M. 2006. Bone Waste Utilization Tuna (Thunnus Sp.) As a Source of Calcium With Protein Hydrolysis Method. Bulletin of Fishery Product Technology 9(2):34-45.

[28]. Wahyuni S. 2011. Histamine Tuna (Thunnus sp.) and Identification of Bacteria Constituent at Standard Storage Temperature Conditions. [Essay]. Bogor: Fishery Product Technology IPB.

[29]. Wellyalina, Azima F, Aisman. 2013. Influence Comparison Tuna and Cornstarch to the Quality of The Nugget. Journal of Food Technology Applications 2(1): 9-17.

[30]. Zaitzev V, Kizevetter I, Lagunov L, Makarova T, Minder L dan Podsevalov V. 1969. Fish Curing and Processing. Mir Publisher. Moscow.

[31]. Haslam, S.M. 1995. River Pollution and Ecological Perspective. John Wiley and Sons, Chichester, UK. 